\title{
In Vitro Anti-Inflammatory Effects of Three Fatty Acids from Royal Jelly
}

\author{
Yi-Fan Chen, ${ }^{1}$ Kai Wang, ${ }^{2}$ Yan-Zheng Zhang, ${ }^{1}$ Yu-Fei Zheng, ${ }^{1}$ and Fu-Liang Hu ${ }^{1}$ \\ ${ }^{1}$ College of Animal Sciences, Zhejiang University, Hangzhou 310058, China \\ ${ }^{2}$ Institute of Apicultural Research, Chinese Academy of Agricultural Sciences, Beijing 100093, China \\ Correspondence should be addressed to Fu-Liang Hu; flhu@zju.edu.cn
}

Received 8 August 2016; Accepted 18 September 2016

Academic Editor: Jie Yin

Copyright (c) 2016 Yi-Fan Chen et al. This is an open access article distributed under the Creative Commons Attribution License, which permits unrestricted use, distribution, and reproduction in any medium, provided the original work is properly cited.

\begin{abstract}
Trans-10-hydroxy-2-decenoic acid (10-H2DA), 10-hydroxydecanoic acid (10-HDAA), and sebacic acid (SEA) are the three major fatty acids in royal jelly (RJ). Previous studies have revealed several pharmacological activities of 10-H2DA and 10-HDAA, although the anti-inflammatory effects and underlying mechanisms by which SEA acts are poorly understood. In the present study, we evaluated and compared the in vitro anti-inflammatory effects of these RJ fatty acids in lipopolysaccharide-stimulated RAW 264.7 macrophages. The results showed that 10-H2DA, 10-HDAA, and SEA had potent, dose-dependent inhibitory effects on the release of the major inflammatory-mediators, nitric oxide, and interleukin-10, and only SEA decreased TNF- $\alpha$ production. Several key inflammatory genes have also been modulated by these RJ fatty acids, with 10-H2DA showing distinct modulating effects as compared to the other two FAs. Furthermore, we found that these three FAs regulated several proteins involved in MAPK and NF- $\kappa$ B signaling pathways. Taken together, these findings provide additional references for using RJ against inflammatory diseases.
\end{abstract}

\section{Introduction}

Royal jelly (RJ) is a viscous secretion from the mandibular and hypopharyngeal glands of worker bees (Apis mellifera) and is known as an essential food for the queens [1]. RJ is also an important functional substance that has been widely used in commercial products, dietary supplements, and cosmetics [2]. RJ has been shown to possess versatile bioactive properties such as antibacterial [3], immunomodulatory [4], antiviral [5], wound-healing [6], growth promoting [7], antioxidant [8], nephroprotective [9], and anti-inflammatory [10] activities. Fresh RJ consists of water (50-60\%), lipids (3$8 \%)$, proteins $(18 \%)$, carbohydrates (7-18\%), and other trace elements [11]. The lipid composition of RJ comprises 80$85 \%$ fatty acids, together with proteins that contribute to its biological activities [12].

Fatty acids (FAs) can be classified as long-chain (more than $12 \mathrm{C}$ ), medium-chain (6-12 C), and short-chain (less than $6 \mathrm{C}$ ) fatty acids, of which medium-chain fatty acids (MCFAs) exist mostly in the free form [13]. The major MCFAs found in RJ are trans-10-hydroxy-2-decenoic acid
(10-H2DA), 10-hydroxydecanoic acid (10-HDAA), and sebacic acid (SEA) (Figure 1) [14]. Trans-10-hydroxy-2decenoic acid (10-H2DA), an unsaturated hydroxyl fatty acid, is predominant and is one of the most extensively studied MCFAs in RJ, constituting more than $50 \%$ of the free FAs. A saturated hydroxyl fatty acid, 10-HDAA, comprises $60-80 \%$ of the total FAs, together with 10-H2DA. SEA (1, 10-decanedioic acid), a dicarboxylic fatty acid, accounts for $3.3 \%$ of the FA family found in the RJ $[15,16]$. Chemical characteristics of FAs in RJ have been determined by gas chromatography-mass spectrometry (GC-MS), high performance liquid chromatography (HPLC), and ultraperformance liquid chromatography (UPLC) methods from lyophilized royal jelly [17-19]. Previous studies have investigated the ability of SEA to inhibit histone deacetylase [20] and modulate the estrogen receptor [21]. Both 10H2DA and 10-HDAA have been shown to possess diverse pharmacological activities such as immunomodulatory [22], estrogenic [21, 23], and anti-inflammatory effects [24] in vitro. In vivo models demonstrated that $10-\mathrm{H} 2 \mathrm{DA}$ effectively protected against the depression and anxiety in mice when 


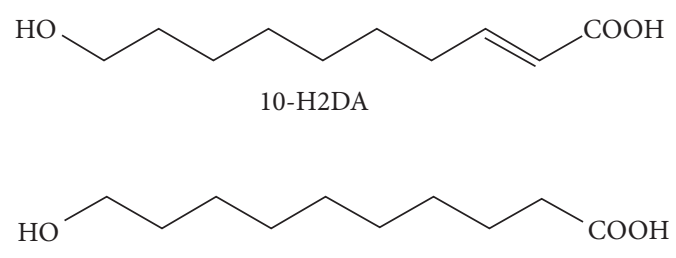

10-HDAA

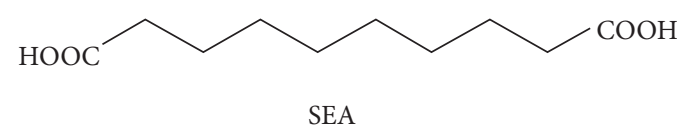

Figure 1: Chemical structures of 10-H2DA, 10-HDAA, and SEA.

intraperitoneally administered [25]. However, the pharmacological activities of SEA have remained elusive. Owing to similarities in the chemical structures of the three abovementioned MCFAs, we hypothesized that SEA may also exhibit similar pharmacological activities.

Inflammation is an important host response of tissues to injury or infection, which may be triggered by chemical toxins, mechanical injuries, and many other reactions. Cell cytokines, like interleukin-6 (IL-6), IL-10, and tumor necrosis factor- $\alpha$ (TNF- $\alpha$ ), play important roles in mediating inflammation [26]. Mitogen-activated protein kinases (MAPKs) comprise protein kinases that participate in the regulation of key cellular processes like inflammatory responses. Extracellular signal-regulated kinases (ERKs), p38, and c-Jun Nterminal kinase (JNK) are the major classes of MAPKs that play important roles in pathogenesis [27, 28]. Additionally, extensive studies have focused on determining the function and regulation of the nuclear factor- $\kappa \mathrm{B}(\mathrm{NF}-\kappa \mathrm{B})$ signaling pathway [29].

Previous studies have reported that $10-\mathrm{H} 2 \mathrm{DA}$ inhibits lipopolysaccharide- (LPS-) induced IL-6 production in a dose-dependent manner [30] and 10-H2DA inhibits LPS and IFN- $\beta$ induced NO production via inhibition of NF- $\kappa$ B [31]. Additionally, 10-HDAA could also inhibit LPS-induced NO production by inhibiting the translation of IRF-1 [32]. However, studies concerning the biological activities of other FAs in the RJ, like 10-HDAA, and SEA are still limited. In the present study, we investigated and compared the antiinflammatory activities of 10-H2DA, 10-HDAA, and SEA in LPS-stimulated RAW 264.7 cells. Our results revealed for the first time that all the three FAs exerted strong biological activities via multiple mechanisms and provided evidence for further functional usage of RJ.

\section{Materials and Methods}

2.1. Chemicals and Reagents. 10-H2DA, 10-HDAA, SEA, and LPS (Escherichia coli 0111:B4) and alkaline phosphataseconjugated secondary antibody (anti-rabbit IgG) were purchased from Sigma (St. Louis, USA). Primary antibodies against $\beta$-tubulin, phospho-ERK1/2, phospho-JNK1/2, phospho-c-Jun (pS63), phospho-I $\kappa \mathrm{B} \alpha$ (pS36), and phosphop65 were purchased from Abcam (Cambridge, Massachusetts, USA). Primary antibody against phospho-p38 (Thr180/ Tyr182) was purchased from Cell Signaling Technology (Danvers, MA, USA). Griess reagent, $\mathrm{NaNO}_{2}$, and other chemicals of analytical grade were purchased from Sangon Biotechnology, Co. Ltd. (Shanghai, China).

2.2. Cell Culture and Cell Viability Assay. Murine macrophage RAW 264.7 cells were a generous gift from Professor Zongping Xia (Life Sciences Institute, Zhejiang University, China). Cells were cultured in high glucose DMEM containing $10 \%$ fetal bovine serum (FBS), $100 \mathrm{U} / \mathrm{mL}$ penicillin, and $100 \mathrm{U} / \mathrm{mL}$ streptomycin at $37^{\circ} \mathrm{C}$ in a $5 \% \mathrm{CO}_{2}$ atmosphere. 10-H2DA, 10-HDAA, and SEA were dissolved in dimethyl sulphoxide (DMSO) before adding them to the culture media at the indicated concentrations. The cell viability was measured using the CCK-8 (cell counting kit-8) (Dojindo, Japan) according to the manufacturer's instructions. Cells were seeded into 96-well cell culture plates and were cultured in the presence of various concentrations of 10-H2DA, 10-HDAA, and SEA after $24 \mathrm{~h}$ incubation. After $24 \mathrm{~h}$, the cells were incubated with $10 \mu \mathrm{L}$ of CCK- 8 at $37^{\circ} \mathrm{C}$ for $2 \mathrm{~h}$. The optical density (OD) was measured at $450 \mathrm{~nm}$ using a microplate reader (Bio-Rad, Model 550, CA).

\subsection{Determination of $\mathrm{NO}$ and Inflammatory Cytokine Pro-} duction. Murine RAW 264.7 cells $\left(1 \times 10^{5}\right)$ were seeded into 24-well plates and cultured for $24 \mathrm{~h}$. Thereafter, the cells were pretreated with specified concentrations of 10 H2DA, 10-HDAA, and SEA for $1 \mathrm{~h}$, following which they were stimulated with $1 \mu \mathrm{g} / \mathrm{mL}$ LPS. After the $24 \mathrm{~h}$ incubation, the cell supernatants were collected, dispensed, and stored at $-80^{\circ} \mathrm{C}$ until further testing. The amounts of the inflammatory-related cytokines (IL-6, IL-10, and TNF- $\alpha$ ) in the cell culture supernatants were measured using enzymelinked immunosorbent assay (ELISA) kits (Boster Company, Wuhan, China). The generation of NO was measured with Griess reagent [33]. The optical density was measured at $450 \mathrm{~nm}$ for IL-6, IL-10, and TNF- $\alpha$ and $550 \mathrm{~nm}$ for NO.

2.4. RNA Isolation and Quantitative Real-Time Polymerase Chain Reaction ( $q R T-P C R$ ). Total RNA from RAW 264.7 cells was extracted using commercial RNA extraction kits (Aidlab Biotechnologies Co. Ltd., Beijing, China) according to the manufacturer's protocols. The concentration of RNA in the samples was measured by NanoDrop spectrophotometer (ND-2000, NanoDrop Technologies, USA) and stored at $-80^{\circ} \mathrm{C}$ until further use. For cDNA synthesis, one microgram of the RNA sample was used with the PrimeScript RT Master Mix (TaKaRa, Dalian, China). The primers presented in Table 1 were synthesized by Sangon Biotechnology (Shanghai, China). Quantitative real-time PCR was performed using StepOne Plus (Applied Biosystems, Carlsbad, CA, USA) with a SYBR Premix Ex Taq (TaKaRa, Dalian, China) via 
TABLE 1: Primer sequences used for qRT-PCR experiments.

\begin{tabular}{|c|c|c|c|}
\hline Gene & Primer sequence & Product size (bp) & GenBank accession no. \\
\hline \multirow{2}{*}{ IL-6 } & $5^{\prime}$-CTCTGCAAGAGACTTCCATCC-3' & \multirow[t]{2}{*}{210} & \multirow{2}{*}{ NM_031168.1 } \\
\hline & $5^{\prime}$-GAATTGCCATTGCACAACTC-3' & & \\
\hline \multirow{2}{*}{ IL-10 } & $5^{\prime}$-CTATGCTGCCTGCTCTTACTG-3' & \multirow{2}{*}{221} & \multirow{2}{*}{ NM_010548.2 } \\
\hline & $5^{\prime}$-CAACCCAAGTAACCCTTAAAGTC-3' & & \\
\hline \multirow{2}{*}{ iNOS } & $5^{\prime}$-TTTCCAGAAGCAGAATGTGACC-3' & \multirow{2}{*}{294} & \multirow{2}{*}{ NM_010927.3 } \\
\hline & $5^{\prime}$-АACACCACTTTCACCAAGACTC-3' & & \\
\hline \multirow{2}{*}{$\mathrm{COX}-2$} & $5^{\prime}$-GAAATATCAGGTCATTGGTGGAG-3’ & \multirow{2}{*}{237} & \multirow{2}{*}{ NM_011198.3 } \\
\hline & 5'-GTTTGGAATAGTTGCTCATCAC-3’ & & \\
\hline \multirow{2}{*}{ TNF- $\alpha$} & $5^{\prime}$-CCACGCTCTTCTGTCTACTG-3' & \multirow{2}{*}{169} & \multirow{2}{*}{ NM_013693.2 } \\
\hline & $5^{\prime}$-ACTTGGTGGTTTGCTACGAC-3' & & \\
\hline \multirow{2}{*}{ HO-1 } & $5^{\prime}$-ACATTGAGCTGTTTGAGGAG-3' & \multirow{2}{*}{241} & \multirow{2}{*}{ NM_010442.2 } \\
\hline & $5^{\prime}$-TACATGGCATAAATTCCCACTG-3' & & \\
\hline \multirow{2}{*}{ GAPDH } & $5^{\prime}$-GAGAAACCTGCCAAGTATGATGAC-3' & \multirow{2}{*}{212} & \multirow{2}{*}{ NM_008084.2 } \\
\hline & 5'-TAGCCGTATTCATTGTCATACCAG-3' & & \\
\hline
\end{tabular}

a standard two-step PCR. The reaction volume was $10 \mu \mathrm{L}$ per well in a 96-well plate format. Specificity was confirmed by carrying out dissociation curve analysis. The housekeeping gene GAPDH was used to normalize the expression of the other target genes, and the results were expressed as $2^{-\Delta \Delta C t}$ [34].

2.5. Cellular Protein Extraction and Immunoblot Analysis. RAW 264.7 cells were pretreated with the assigned concentrations of 10-H2DA, 10-HDAA, and SEA for $1 \mathrm{~h}$ and then stimulated with $1 \mu \mathrm{g} / \mathrm{mL}$ LPS for $30 \mathrm{~min}$. Further, the cells were put on ice and washed immediately with precold PBS twice. The cytoplasmic proteins were lysed with NP40 mixed with protease inhibitors and phosphatase inhibitors (Roche, Basel, Switzerland), and the cell lysate was collected using cell scrapers (Corning, New York), following which it was vortexed and put on ice for $10 \mathrm{~min}$ to remove the cell debris. Equal amounts of cellular protein $(30 \mu \mathrm{g})$ were then mixed with Laemmli's sample buffer and boiled at $95^{\circ} \mathrm{C}$ for $10 \mathrm{~min}$. The concentration of the protein was measured by the BCA protein assay kit (Weiao Biotechnology, Shanghai, China). The proteins were separated by $10 \%$ sodium dodecyl sulphate-polyacrylamide gel electrophoresis (SDS-PAGE) and then transferred to polyvinylidene difluoride membrane (Millipore, Billerica, MA). Skim milk (5\%) dissolved in Trisbuffered saline Tween 20 was used to block the nonspecific binding sites for $30 \mathrm{~min}$ at room temperature. The membranes were blotted using specific antibodies in combination with AP-conjugated anti-rabbit secondary antibodies with a 1:5000 dilution. The protein bands on the membranes were developed by the NBT/BCIP method [35] and the results were evaluated using Quantity One software.

2.6. Statistical Analysis. Data are expressed as the means \pm SEM for the indicated number of independently performed experiments. Statistical comparison of the data was performed by Student's $t$-test or one-way ANOVA following Student-Newman-Keuls method. $P$ values $<0.05$ were considered statistically significant. Statistical tests were carried out using SPSS software version 22.0 and GraphPad Prism 6.0 software.

\section{Results}

3.1. Effects of 10-H2DA, 10-HDAA, and SEA on RAW 264.7 Cell Viability. To ensure that 10-H2DA, 10-HDAA, or SEA do not have any toxic effects on cell metabolism and to determine the optimal concentrations for further experiments, the effects of these fatty acids on cell viability were assessed in RAW 264.7 cells using the CCK-8 assay. Figure 2 shows the results of cell viability after $24 \mathrm{~h}$ of incubation using different concentrations of 10-H2DA (Figure 2(a)), 10-HDAA (Figure 2(b)), and SEA (Figure 2(c)). Treatments with the three fatty acids $(0,1,2.5$, and $5 \mathrm{mM})$ for $24 \mathrm{~h}$ did not cause any significant changes in the viability compared to the control group. The acids also did not show any toxicity in RAW 264.7 cells at concentrations up to $5 \mathrm{mM}$; however, higher concentrations $(8 \mathrm{mM})$ were found to be toxic. Statistically significant decreases in cell survival were detected at concentrations up to $8 \mathrm{mM}$. Based on these results, we chose FA concentrations up to $5 \mathrm{mM}$ for the subsequent experiments.

3.2. Effects of 10-H2DA, 10-HDAA, and SEA on the Production of NO and Inflammatory-Related Cytokines in LPS-Stimulated RAW 264.7 Cells. NO production was estimated using Greiss' reaction and is shown in Figure 3. The inflammatory cytokines in the cell medium were analyzed using ELISA assays as shown in Figures 4(a)-4(c). After a $24 \mathrm{~h}$ incubation period, 


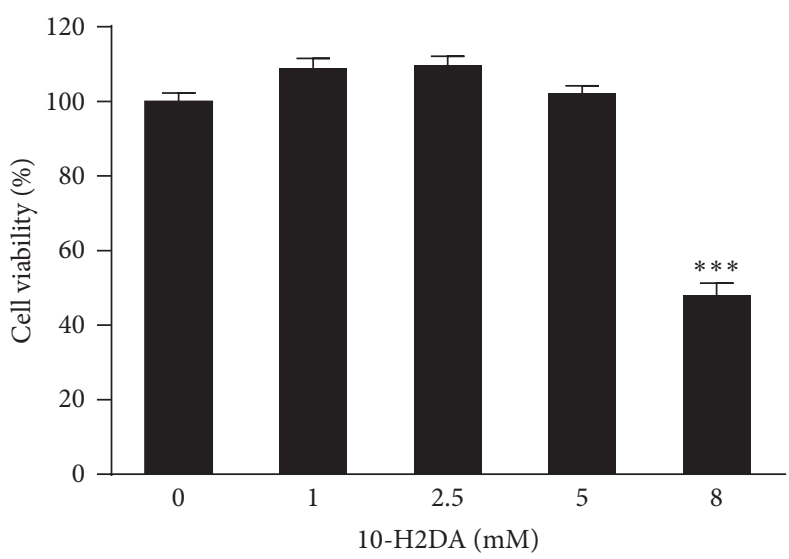

(a)

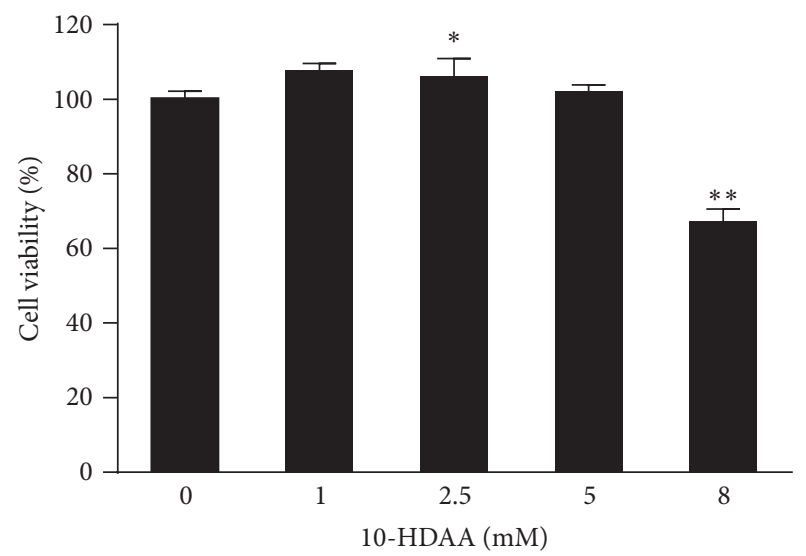

(b)

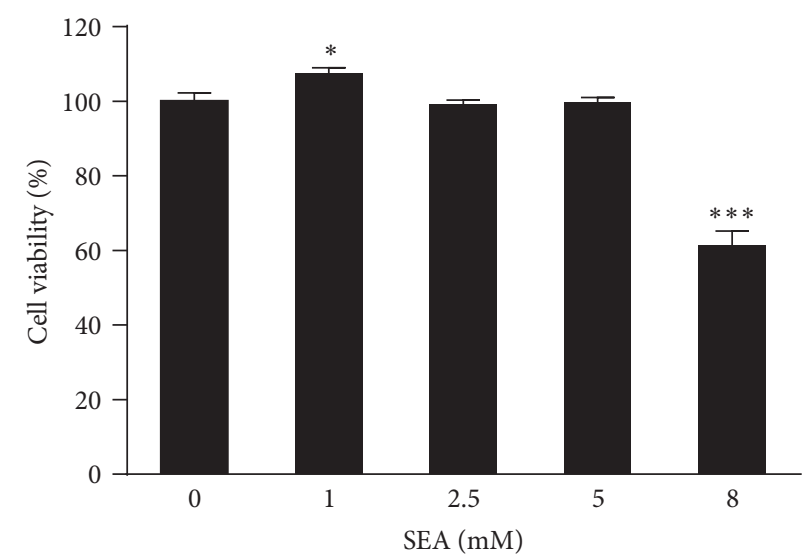

(c)

FIGURE 2: Effects of 10-H2DA, 10-HDAA, and SEA on the viability of RAW 264.7 cells. RAW 264.7 cells were treated with the indicated concentrations of 10-H2DA (a), 10-HDAA (b), and SEA (c) (0-8 mM) for $24 \mathrm{~h}$, and the results are expressed as percentages of surviving cells over control cells, by CCK- 8 assays. The data are the means \pm SEMs for three independent experiments. ${ }^{*} P<0.05,{ }^{* *} P<0.01$, and ${ }^{* * *} P<0.001$ versus control cells by Student's $t$-test.

very low amounts of NO and the three cytokines, IL-6, IL-10, and TNF- $\alpha$, were detected in the absence of LPS. When the cells were stimulated with LPS $(1 \mu \mathrm{g} / \mathrm{mL})$, the production of $\mathrm{NO}$ and the cytokines was found to increase markedly. However, pretreatment with the three FAs for $1 \mathrm{~h}$ inhibited NO and IL-10 production in a dose-dependent manner. 10-HDAA and higher concentrations of 10-H2DA decreased IL-6 production. On the other hand, SEA exerted strong inhibitory effects on the production of TNF- $\alpha$, which was different compared to those seen with the other two FAs.

3.3. Effects of 10-H2DA, 10-HDAA, and SEA on the mRNA Expression of Key Inflammatory-Mediators and Cytokine Genes in LPS-Stimulated RAW 264.7 Cells. To evaluate the effects of 10-H2DA, 10-HDAA, and SEA on mRNA expressions in LPS-stimulated RAW 264.7 cells, we chose six key genes involved in the inflammatory response and measured their gene expression using quantitative real-time PCR. The RAW 264.7 cells were stimulated with LPS alone or LPS and 10-H2DA, 10-HDAA, and SEA for $6 \mathrm{~h}$. LPS caused significant increase in the transcription of the inflammatoryrelated genes (Figures 5(a)-5(f)). Pretreatment with the three FAs decreased IL-10, iNOS, and COX-2 mRNA expressions (Figures 5(b)-5(d)). Additionally, low doses of 10-H2DA and SEA ( $1 \mathrm{mM}$ ) slightly increased the mRNA expression of IL-6; however, 10-HDAA, 10-H2DA, and SEA, at a concentration of $5 \mathrm{mM}$, each, inhibited the mRNA expression of IL- 6 . Compared to that in the LPS-stimulated group, 10-H2DA and 10-HDAA $(2.5,5 \mathrm{mM})$ increased the mRNA expression of TNF- $\alpha$; however, SEA caused strong inhibition of TNF$\alpha$ mRNA transcription. Similar effects of SEA appeared to occur with HO-1 mRNA expression, and 10-H2DA exhibited a stronger enhancement of $\mathrm{HO}-1$ production as compared to 10-HDAA.

3.4. Effects of 10-H2DA, 10-HDAA, and SEA on MAPK and NF- $\kappa B$ Signaling Pathways in LPS-Stimulated RAW 264.7 Cells. To further clarify the molecular mechanisms underlying 10-H2DA-, 10-HDAA-, and SEA-mediated effects 


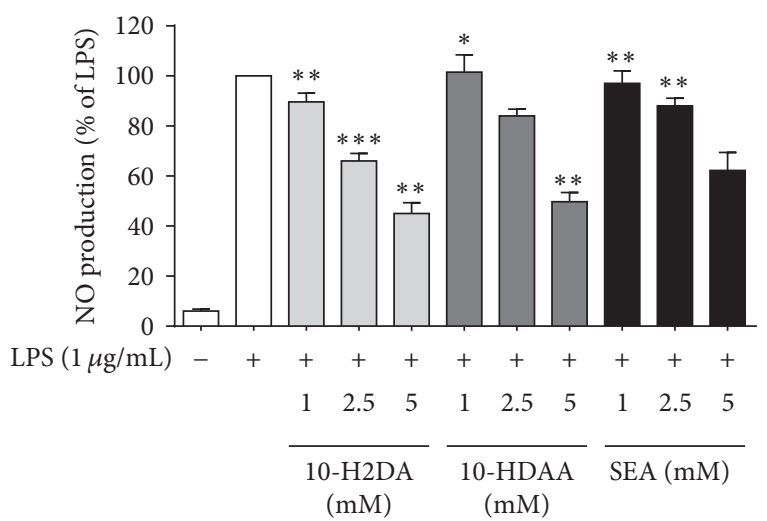

Figure 3: Effects of 10-H2DA, 10-HDAA, and SEA on LPSinduced NO production in RAW 264.7 cells. Cells were pretreated with/without indicated concentrations of 10-H2DA, 10-HDAA, and SEA for $1 \mathrm{~h}$ and then stimulated with LPS $(1 \mu \mathrm{g} / \mathrm{mL})$ for $24 \mathrm{~h}$. Control values were obtained in the absence of LPS and the three fatty acids. The values are presented as percentages of $\mathrm{NO}$ in comparison with LPS-treated cells. The data are the means \pm SEMs for three independent experiments. Individual groups were compared by Student's $t$-test $\left({ }^{*} P<0.05,{ }^{* *} P<0.01\right.$, and ${ }^{* * *} P<0.001$ compared with the LPS group).

on inflammation-related genes, we next used Western blot analysis to characterize the effects on LPS-induced phosphorylation using specific antibodies. Cells were investigated by examining the changes in the expression levels of $\mathrm{I} \kappa \mathrm{B} \alpha$ and phosphorylated c-Jun, ERK1/2, JNK1/2, p38, and p65. As shown in Figure 6, the expression levels of each of these proteins were rapidly activated after treatment with $1 \mu \mathrm{g} / \mathrm{mL}$ LPS. Dose-course experiments showed that all the three FAs attenuated the phosphorylation of c-Jun. Despite the similar modulating effects against the production of inflammatory cytokines, these FAs showed distinct regulatory effects on MAPK and NF- $\kappa$ B proteins. It can be observed that these RJ FAs increased the phosphorylation levels of ERK1/2 when compared to that in the LPS group. The phosphorylation of c-Jun was inhibited by all the RJ FAs. Nevertheless, only SEA blocked the activation of $\mathrm{p} 38$ and JNK1/2. With regard to the NF- $\kappa$ B proteins, 10-HDAA and SEA showed inhibitory effects against NF- $\kappa \mathrm{B}$ activation, since they blocked the activation of p-p65 and SEA ( $2.5 \mathrm{mM})$ upregulated the protein abundance of $\mathrm{I} \kappa \mathrm{B} \alpha$.

\section{Discussions}

The market for functional foods has been expanding annually over the past decades [36]. Natural bee products like honey, propolis, and royal jelly have attracted increasing attention, with the anti-inflammatory activity of propolis being well known and widely studied [37, 38]. Investigations of honey and RJ in inflammation are relatively rare and generally focus on its major proteins. Previous studies reported that the major RJ and honey glycoprotein Apalbuminl (Apal) showed significant stimulatory effects on TNF- $\alpha$ production by murine peritoneal macrophages [39]. Similar results were also observed in major honeybee royal jelly protein 1 (MRJP1) [40]. Nevertheless, our studies provide first-hand evidence that the FAs in the RJ showed distinctive anti-inflammatory effects.

Macrophages are innate immune cells which could be activated and release various inflammatory cytokines and chemokines when induced by LPS [41]. During the inflammatory process, $\mathrm{NO}$ is generated in the macrophages by inducible NO synthase (iNOS) in response to LPS. Similar to a previous study [32], we found that $10-\mathrm{H} 2 \mathrm{DA}$ and $10-$ HDAA significantly inhibited LPS-induced NO production and iNOS mRNA expression. Moreover, we observed that SEA also attenuated the production of NO and decreased iNOS gene expression, but the effect was weaker compared to the other two FAs. Kohno et al. showed that MRJP3 and some lower molecular compounds in RJ efficiently inhibited the production of proinflammatory cytokines in LPS and IFN- $\gamma$ costimulated mouse peritoneal macrophages [42]. Our ELISA results showed that the three FAs decreased LPSinduced production of IL- 6 at higher concentrations and SEA had strong inhibitory activity against TNF- $\alpha$ production, thus indicating that $10-\mathrm{H} 2 \mathrm{DA}, 10-\mathrm{HDAA}$, and SEA are part of those active lower molecular compounds. A previous study has shown that LPS-induced mRNA expression of IL- 6 and TNF- $\alpha$ was not decreased by 10-HDAA at the time points of $3,6,12$, and $24 \mathrm{~h} \mathrm{[32].} \mathrm{In} \mathrm{our} \mathrm{study,} \mathrm{we} \mathrm{also} \mathrm{detected} \mathrm{that}$ 10-HDAA showed a slight inhibition of IL- 6 production and had no significant effect on TNF- $\alpha$ production at various concentrations. These findings are in agreement with the results of previous studies, indicating that $10-\mathrm{H} 2 \mathrm{DA}, 10-$ HDAA, and SEA could reduce inflammatory responses by inhibiting mRNA expression of target genes.

Cyclooxygenase-2 (COX-2) and IL-10 are two important cytokines that are closely related to the inflammatory process $[43,44]$. Cyclooxygenase (COX) enzymes catalyse the committed step in prostanoid synthesis, converting free arachidonic acid into the prostaglandin (PG) precursors. COX-2 is induced by proinflammatory stimuli; drugs that block COX-2 activity could have anti-inflammation actions [45]. IL-10 is known as a key anti-inflammatory cytokine which is activated during the resolution stage of inflammation [37]. LPS-induced mRNA levels of COX-2 and IL10 were markedly reduced by pretreatment with the three FAs in a dose-dependent manner suggesting that they showed similar regulation of those transcriptional genes. Additionally, we observed a remarkable enhancement in the effect of 10-H2DA (5 mM) on HO-1 mRNA expression. HO1 mediates an important pathway with anti-inflammatory effects in different experimental models and could be a potential therapeutic target in human inflammatory diseases [46]. Nevertheless, SEA reduced the expression of HO-1 dose dependently, and 10-HDAA showed a slight increase at higher concentrations, suggesting that these FAs possess different modulating mechanisms during the inflammation process.

Previous study indicated that $10-\mathrm{H} 2 \mathrm{DA}$ suppression was likely to be mediated via blocking the p38 kinase and JNKAP-1 signaling pathways and that 10-H2DA had no effect 


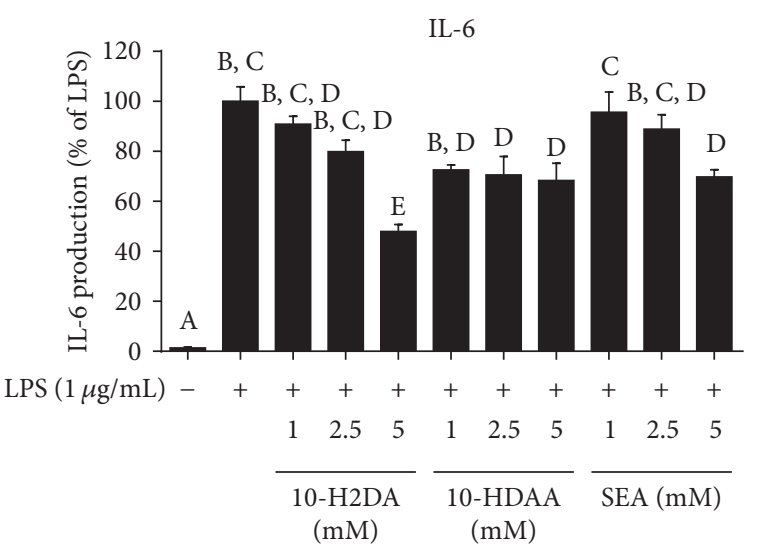

(a)

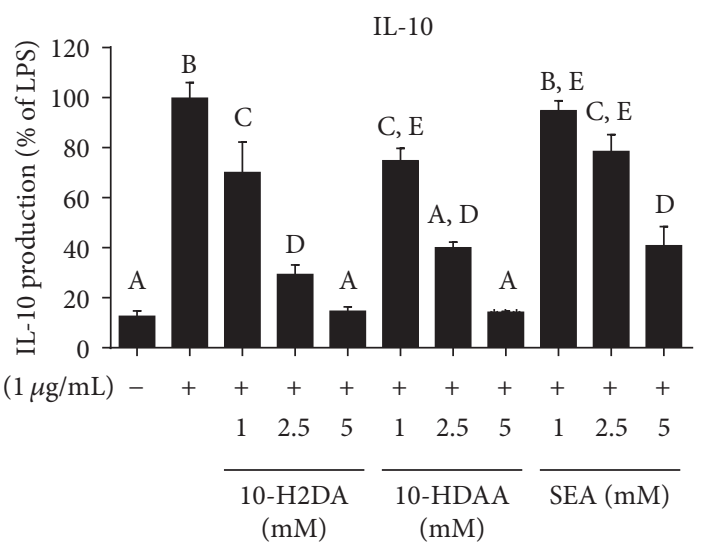

(b)

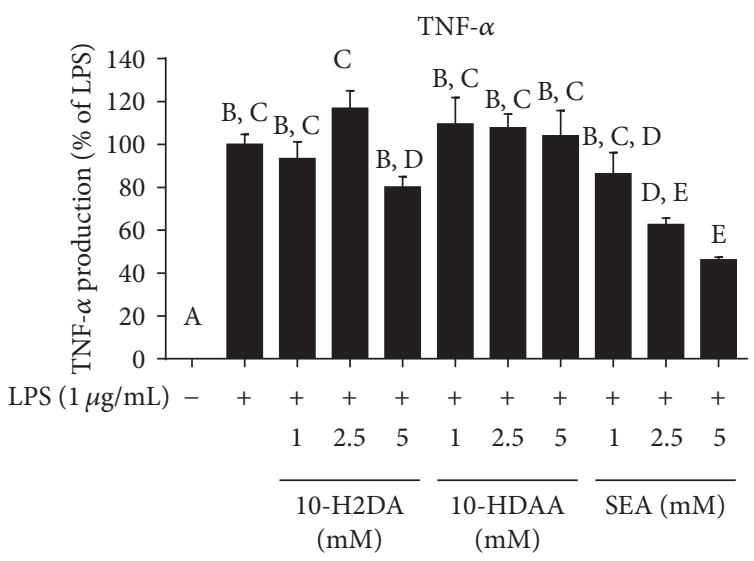

(c)

Figure 4: Effects of 10-H2DA, 10-HDAA, and SEA on LPS-induced IL-6, IL-10, and TNF- $\alpha$ production in RAW 264.7 cells. Cells were pretreated with/without indicated concentrations of 10-H2DA, 10-HDAA, or SEA for $1 \mathrm{~h}$ and then stimulated with LPS $(1 \mu \mathrm{g} / \mathrm{mL})$ for $24 \mathrm{~h}$. Control values were obtained in the absence of LPS or the treatment. The values are presented as percentages of IL-6 (a), IL-10 (b), and TNF- $\alpha$ (c) in comparison with LPS-treated cells, respectively. The data are the means \pm SEMs for three independent experiments. Oneway ANOVA with the Student-Newman-Keuls method was performed to compare all groups; means with different letters are significantly different $(P<0.05)$.

on ERK1/2, NF- $\kappa$ B DNA-binding activity, and $\mathrm{I} \kappa \mathrm{B} \alpha$ degradation in TNF- $\alpha$ induced rheumatoid arthritis synovial fibroblasts [24]. In our study, the expression levels of all MAPK pathway proteins were rapidly phosphorylated after treatment with $1 \mu \mathrm{g} / \mathrm{mL}$ LPS. 10-H2DA blocked the phosphorylation of ERK1/2 at $2.5 \mathrm{mM}$ and slightly elevated the phosphorylation at $5 \mathrm{mM}$. 10-HDAA inhibited JNK1/2 phosphorylation at $2.5 \mathrm{mM}$. SEA $(5 \mathrm{mM})$ regulated the phosphorylation of ERK1/2 and p38 and markedly reduced JNK1/2 phosphorylation. JNK pathway could be strongly activated by proinflammatory agents and was an important event in the cellular response to stress [47]; SEA showed great potential in mediating JNK signaling pathways. In addition, all the three FAs reduced the expression level of $\mathrm{p}$-c-Jun, the AP-1 heterodimer involved in MAPK pathways. NF- $\kappa \mathrm{B}$ plays a crucial role in regulating inflammatory process and thus becomes target for developing novel anti-inflammation treatments [41]. NF- $\kappa \mathrm{B}$ is combined with $\mathrm{I} \kappa \mathrm{B}$, an inhibitory protein which keeps $\mathrm{NF}-\kappa \mathrm{B}$ in an inactive state in the cytoplasm. Induced by LPS, phosphorylation of $\mathrm{I} \kappa \mathrm{B}$ in the $\mathrm{NF}-\kappa \mathrm{B} / \mathrm{I} \kappa \mathrm{B}$ protein complex can release $\mathrm{NF}-\kappa \mathrm{B}$ to translocate from the cytoplasm into the nucleus and then phosphorylated p65 could activate the correlated target genes [48]. Previous research has demonstrated that $10-\mathrm{H} 2 \mathrm{DA}$ could inhibit NF$\kappa \mathrm{B}$ activation via suppressing NO production and $\mathrm{I} \kappa \mathrm{B}-\zeta$ mRNA expression and transcription stimulated by LPS and IFN- $\beta$. Also, immunoblotting revealed that $10-\mathrm{H} 2 \mathrm{DA}$ did not inhibit LPS-induced IKK- $\alpha$ phosphorylation and I $\kappa \mathrm{B} \alpha$ degradation [30]. In our study, 10-H2DA showed modest attenuating effects on $\mathrm{I} \kappa \mathrm{B} \alpha$ and enhanced the phosphorylation of p65, suggesting that $10-\mathrm{H} 2 \mathrm{DA}$ regulated LPS stimulation through more than one single pathway. Nevertheless, 10-HDAA showed no significant effects on those NF$\kappa \mathrm{B}$ pathway proteins. Notably, SEA exerted a strong suppressive effect on $\mathrm{p} 65$ phosphorylation, indicating that SEA inhibited transcription of target genes including iNOS, IL10 , TNF- $\alpha$, and COX-2 mRNA by suppressing the activity of $\mathrm{NF}-\kappa \mathrm{B}$. 


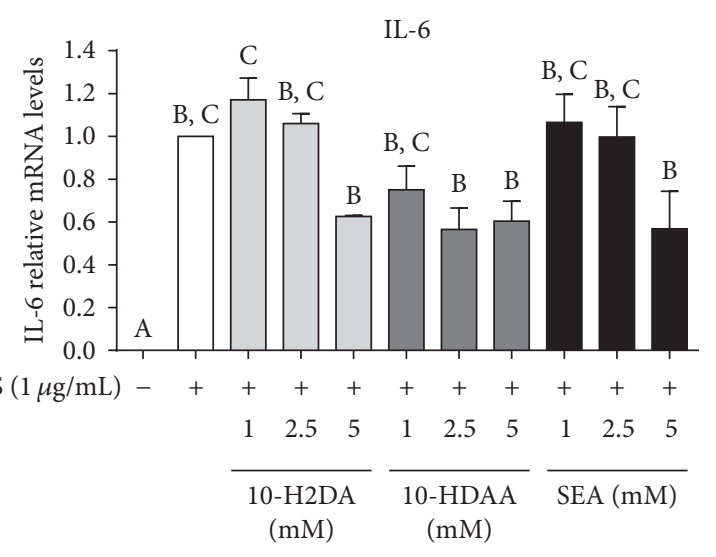

(a)

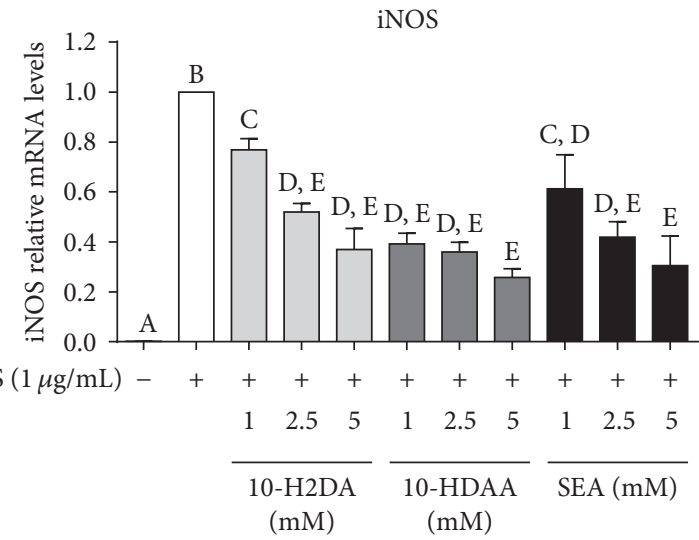

(c)

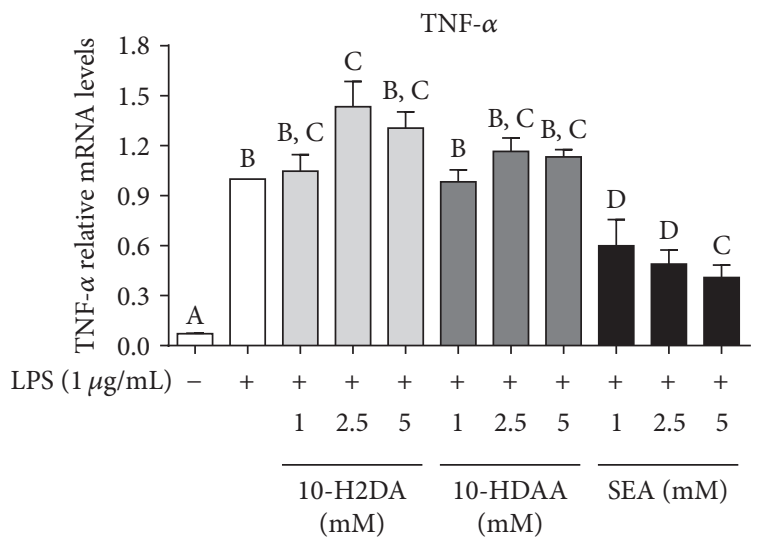

(e)

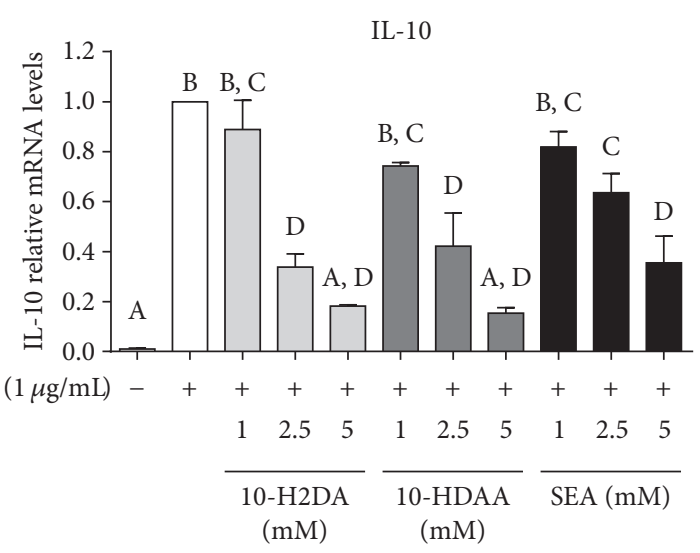

(b)

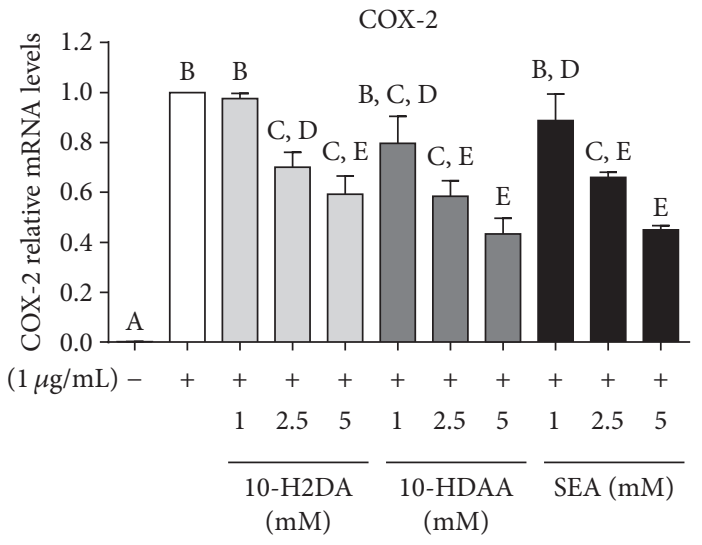

(d)

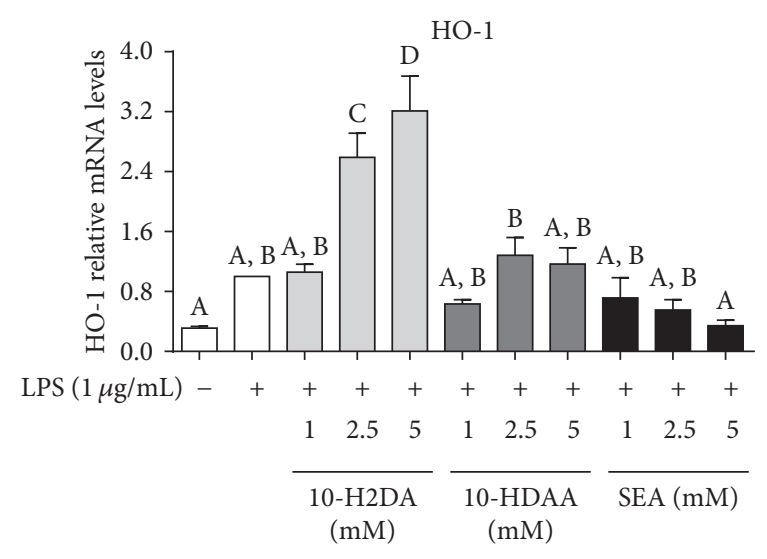

(f)

FIGURE 5: Effects of pretreatment with 10-H2DA, 10-HDAA, and SEA on the mRNA expression of key inflammatory-mediators and cytokine genes in LPS-stimulated RAW 264.7 cells. Effects of 10-H2DA, 10-HDAA, and SEA on the mRNA expression of key inflammatory-mediators and cytokine genes in LPS-stimulated RAW 264.7 cells. Cells were pretreated with 10-H2DA, 10-HDAA, and SEA in designed concentrations for $1 \mathrm{~h}$ and then stimulated with LPS $(1 \mu \mathrm{g} / \mathrm{mL}$ ) for $30 \mathrm{~min}$. The mRNA levels of IL-6 (a), IL-10 (b), iNOS (c), COX-2 (d), TNF- $\alpha$ (e), and HO-1 (f) were quantified using qRT-PCR and normalized to GAPDH and the levels of gene expression in the LPS group were set to 1. Data shown represent means \pm SEM values from three independent experiments. One-way ANOVA with the Student-Newman-Keuls method was performed to compare all groups; means with different letters are significantly different $(P<0.05)$.

\section{Conclusion}

The present study explored the in vitro anti-inflammatory effects of three major FAs from RJ. The results clearly showed that all three FAs present are responsible for the previously reported anti-inflammatory property of RJ, and the role of SEA should be noted. Our findings also indicate that 10$\mathrm{H} 2 \mathrm{DA}$ has the strongest in vitro anti-inflammatory effect 

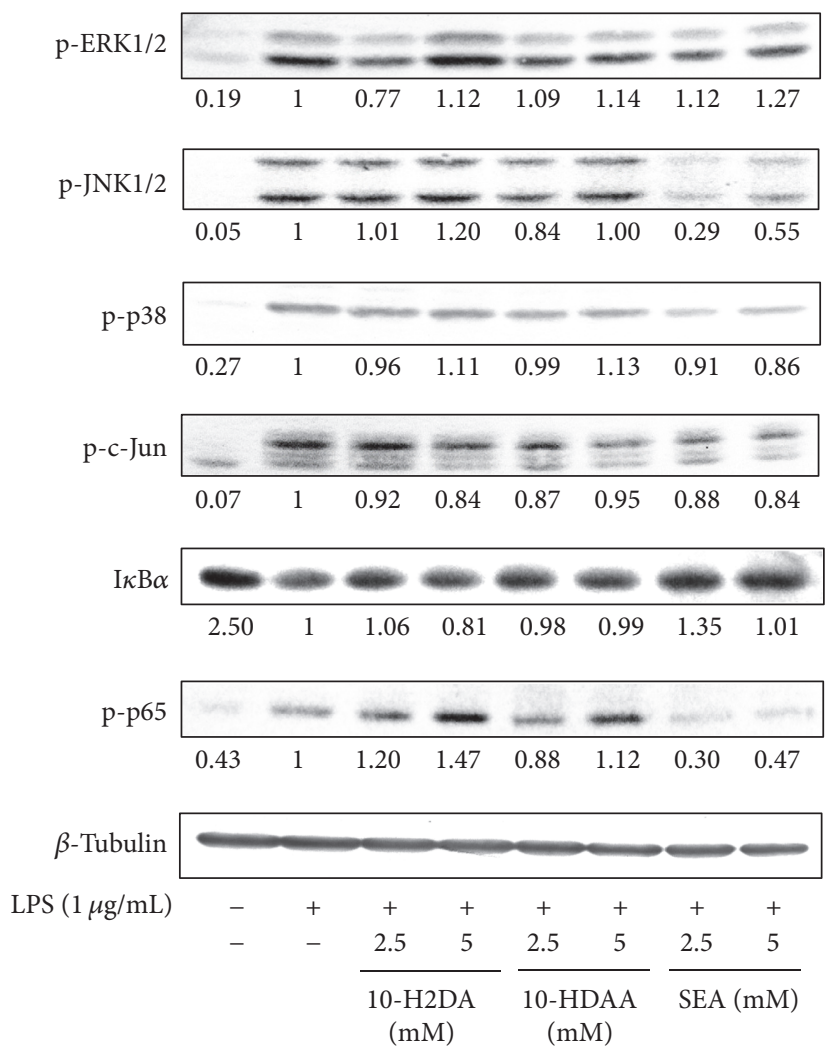

(a)

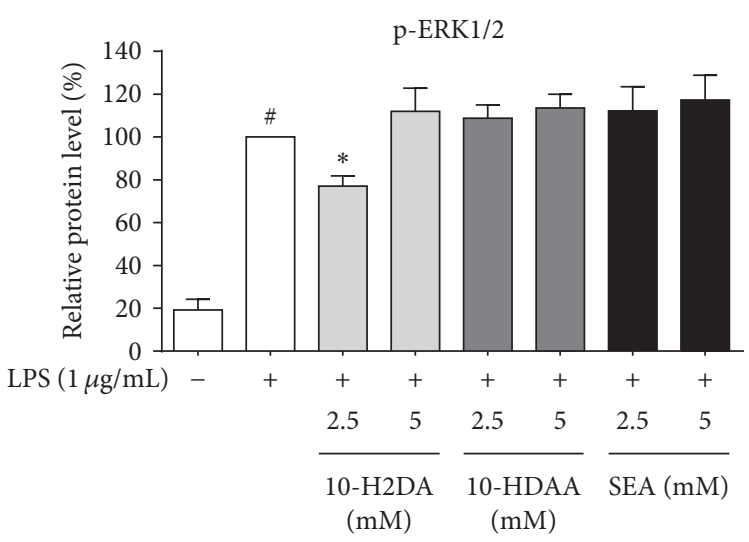

(b)

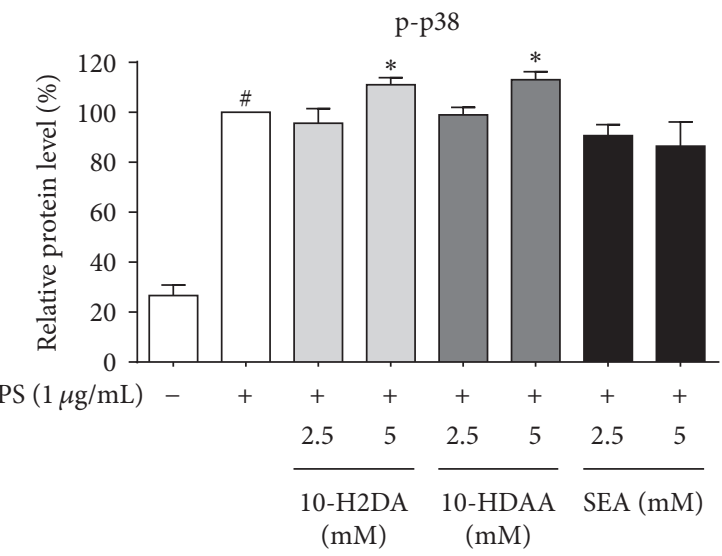

(d)

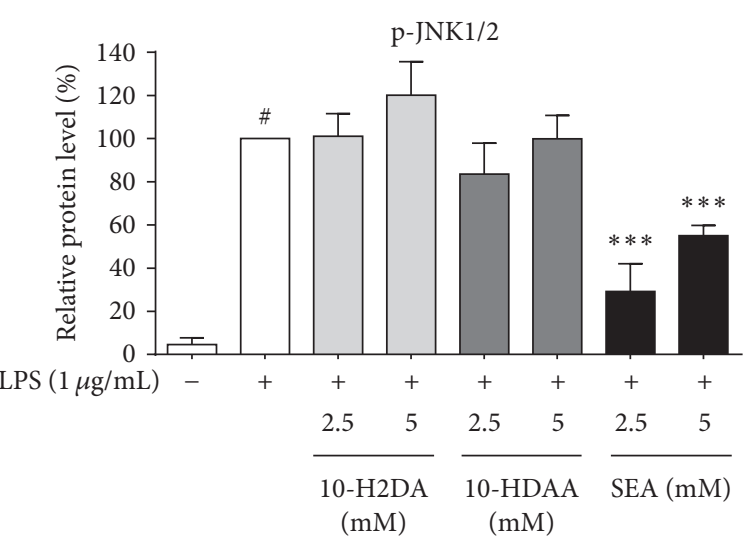

(c)

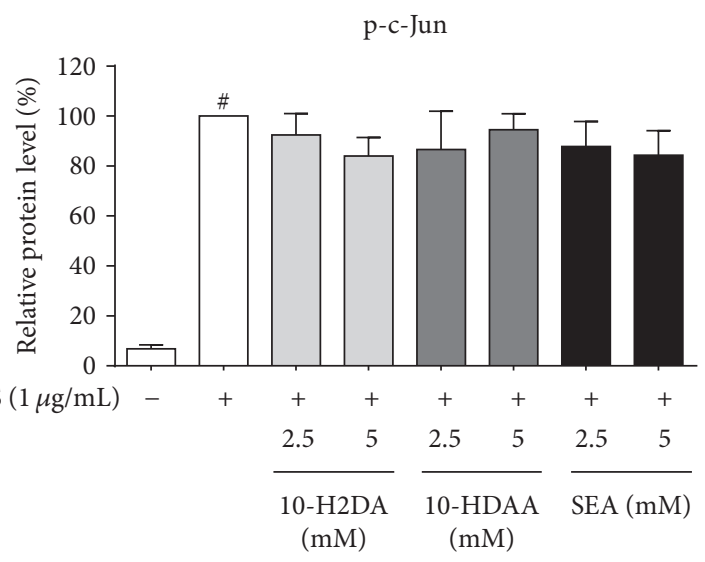

(e)

Figure 6: Continued. 


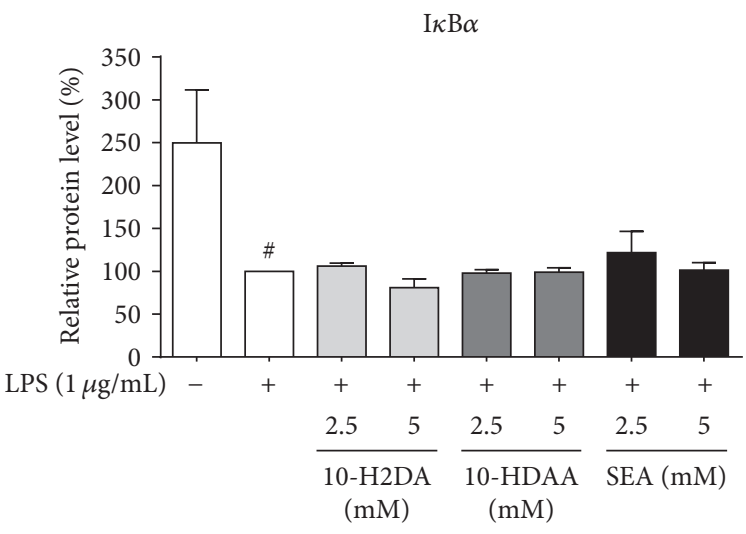

(f)

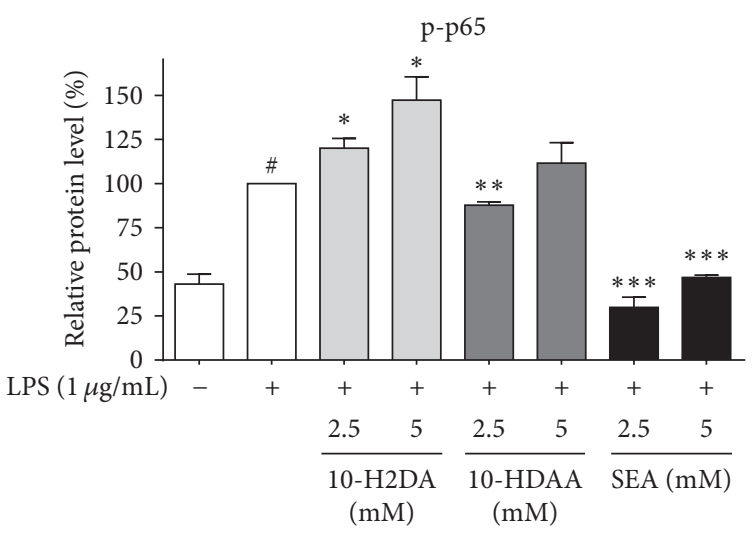

$(\mathrm{g})$

FIGURE 6: Effects of 10-H2DA, 10-HDAA, and SEA on the phosphorylation of MAPK and NF- $\kappa$ B pathways in LPS-stimulated RAW 264.7 cells. (a) RAW 264.7 cells either were pretreated with 10-H2DA, 10-HDAA, and SEA at the indicated concentrations for $1 \mathrm{~h}$ or received no such pretreatment. They were then stimulated with LPS $(1 \mu \mathrm{g} / \mathrm{mL})$ for $30 \mathrm{~min}$. Whole cell lysates were analyzed by Western blotting analysis using specific antibodies. The relative expression of proteins was quantified using Quantity One software, comparing with $\beta$-tubulin. Data shown are the representative of three independent experiments with similar results. (b-g) The intensity of corresponding bands was measured by densitometry and normalized to $\beta$-tubulin. The values are the means \pm SEMs. Individual groups were compared by Student's $t$-test $\left({ }^{*} P<0.05\right.$, ${ }^{* *} P<0.01$, and ${ }^{* * *} P<0.001$ compared with the LPS group; ${ }^{*} P<0.05$ compared with untreated group).

among the three FAs tested, suggesting a possible therapeutic potential against inflammatory diseases.

$\begin{array}{ll}\text { Abbreviations } \\ \text { 10-H2DA: } & \text { Trans-10-hydroxy-2-decenoic acid } \\ \text { 10-HDAA: } & \text { 10-hydroxydecanoic acid } \\ \text { SEA: } & \text { Sebacic acid } \\ \text { LPS: } & \text { Lipopolysaccharide } \\ \text { NO: } & \text { Nitric oxide } \\ \text { TNF- } \alpha: & \text { Tumor necrosis factor- } \alpha \\ \text { IL: } & \text { Interleukin } \\ \text { iNOS: } & \text { Induced nitric oxide synthase } \\ \text { COX-2: } & \text { Cyclooxygenase- } 2 \\ \text { HO-1: } & \text { Heme oxygenase-1 } \\ \text { NF- } \kappa \text { B: } & \text { Nuclear factor- } \kappa \text { B } \\ \text { AP- } 1: & \text { Activator protein-1 } \\ \text { MAPK: } & \text { Mitogen-activated protein kinase. }\end{array}$

\section{Competing Interests}

The authors declare no conflict of interests regarding the publication of this paper.

\section{Acknowledgments}

The research was supported by grants from the National Natural Science Foundation of China (no. 31272512) and the earmarked fund for Modern Agro-Industry Technology Research System from the Ministry of Agriculture of China (CARS-45).

\section{References}

[1] M. Kamakura, "Royalactin induces queen differentiation in honeybees," Nature, vol. 473, no. 7348, pp. 478-483, 2011.

[2] M. F. Ramadan and A. Al-Ghamdi, "Bioactive compounds and health-promoting properties of royal jelly: a review," Journal of Functional Foods, vol. 4, no. 1, pp. 39-52, 2012.

[3] A. P. Nascimento, L. A. R. Moraes, N. U. Ferreira et al., "The lyophilization process maintains the chemical and biological characteristics of royal jelly," Evidence-Based Complementary and Alternative Medicine, vol. 2015, Article ID 825068, 5 pages, 2015.

[4] S. Gasic, D. Vucevic, S. Vasilijic, M. Antunovic, I. Chinou, and M. Colic, "Evaluation of the immunomodulatory activities of royal jelly components in vitro," Immunopharmacology and Immunotoxicology, vol. 29, no. 3-4, pp. 521-536, 2007.

[5] M. H. El-Gayar, K. M. Aboshanab, M. M. Aboulwafa, and N. A. Hassouna, "Antivirulence and wound healing effects of royal jelly and garlic extract for the control of MRSA skin infections," Wound Medicine, vol. 13, pp. 18-27, 2016.

[6] M. K. Rashidi, N. Mirazi, and A. Hosseini, "Effect of topical mixture of honey, royal jelly and olive oil-propolis extract on skin wound healing in diabetic rats," Wound Medicine, vol. 12, pp. 6-9, 2016.

[7] A. Miyashita, H. Kizaki, K. Sekimizu, and C. Kaito, "Bodyenlarging effect of royal jelly in a non-holometabolous insect species, Gryllus bimaculatus," Biology Open, vol. 5, pp. 770-776, 2016.

[8] F. Delkhoshe-Kasmaie, H. Malekinejad, M. Khoramjouy, A. Rezaei-Golmisheh, and H. Janbaze-Acyabar, "Royal jelly protects from taxol-induced testicular damages via improvement of antioxidant status and up-regulation of E2f1," Systems Biology in Reproductive Medicine, vol. 60, no. 2, pp. 80-88, 2014.

[9] A. Ibrahim, M. A. A. Eldaim, and M. M. Abdel-Daim, "Nephroprotective effect of bee honey and royal jelly against subchronic 
cisplatin toxicity in rats," Cytotechnology, vol. 68, no. 4, pp. 10391048, 2016.

[10] C. I. Pavel, L. A. Marghitas, O. Bobis et al., "Biological activities of royal jelly-review," Scientific Papers Animal Science and Biotechnologies, vol. 44, no. 2, pp. 108-118, 2011.

[11] A. G. Sabatini, G. L. Marcazzan, M. F. Caboni, S. Bogdanov, and L. Almeida-Muradian, "Quality and standardisation of royal jelly," Journal of ApiProduct and ApiMedical Science, vol. 1, no. 1, pp. 1-6, 2009.

[12] G. Lercker, P. Capella, L. S. Conte, F. Ruini, and G. Giordani, "Components of royal jelly: I. Identification of the organic acids," Lipids, vol. 16, no. 12, pp. 912-919, 1981.

[13] X. Li, C. Huang, and Y. Xue, "Contribution of Lipids in Honeybee (Apis mellifera) royal jelly to health," Journal of Medicinal Food, vol. 16, no. 2, pp. 96-102, 2013.

[14] Y. Terada, M. Narukawa, and T. Watanabe, "Specific hydroxy fatty acids in royal jelly activate TRPA1," Journal of Agricultural and Food Chemistry, vol. 59, no. 6, pp. 2627-2635, 2011.

[15] N. Noda, K. Umebayashi, T. Nakatani, K. Miyahara, and K. Ishiyama, "Isolation and characterization of some hydroxy fatty and phosphoric acid esters of 10-hydroxy-2-decenoic acid from the royal jelly of honeybees (Apis mellifera)," Lipids, vol. 40, no. 8, pp. 833-838, 2005.

[16] F. Ferioli, G. L. Marcazzan, and M. F. Caboni, "Determination of (E)-10-hydroxy-2-decenoic acid content in pure royal jelly: a comparison between a new CZE method and HPLC," Journal of Separation Science, vol. 30, no. 7, pp. 1061-1069, 2007.

[17] V. A. Isidorov, U. Czyzewska, A. G. Isidorova, and S. Bakier, “Gas chromatographic and mass spectrometric characterization of the organic acids extracted from some preparations containing lyophilized royal jelly," Journal of Chromatography B: Analytical Technologies in the Biomedical and Life Sciences, vol. 877, no. 29, pp. 3776-3780, 2009.

[18] J. Zhou, J. Zhao, H. Yuan et al., "Comparison of UPLC and HPLC for determination of trans-10-hydroxy-2- decenoic acid content in royal jelly by ultrasound-assisted extraction with internal standard," Chromatographia, vol. 66, no. 3-4, pp. 185190, 2007.

[19] V. A. Isidorov, U. Czyzewska, A. G. Isidorova, and S. Bakier, "Gas chromatographic and mass spectrometric characterization of the organic acids extracted from some preparations containing lyophilized royal jelly," Journal of Chromatography B, vol. 877, no. 29, pp. 3776-3780, 2009.

[20] J. Makino, R. Ogasawara, T. Kamiya et al., "Royal jelly constituents increase the expression of extracellular superoxide dismutase through histone acetylation in monocytic THP-1 cells," Journal of Natural Products, vol. 79, no. 4, pp. 1137-1143, 2016.

[21] P. Moutsatsou, Z. Papoutsi, E. Kassi et al., "Fatty acids derived from royal jelly are modulators of estrogen receptor functions," PLoS ONE, vol. 5, no. 12, Article ID e15594, 2010.

[22] D. Mihajlovic, I. Rajkovic, I. Chinou, and M. Colic, "Dosedependent immunomodulatory effects of 10-hydroxy-2decenoic acid on human monocyte-derived dendritic cells," Journal of Functional Foods, vol. 5, no. 2, pp. 838-846, 2013.

[23] K.-M. Suzuki, Y. Isohama, H. Maruyama et al., "Estrogenic activities of fatty acids and a sterol isolated from royal jelly," Evidence-Based Complementary and Alternative Medicine, vol. 5, no. 3, pp. 295-302, 2008.

[24] X.-Y. Yang, D.-S. Yang, Wei-Zhang et al., "10-Hydroxy-2decenoic acid from Royal jelly: a potential medicine for RA," Journal of Ethnopharmacology, vol. 128, no. 2, pp. 314-321, 2010.
[25] S. Furukawa, S. Ito, Y. Nitta et al., "Antidepressant-like activity of 10-hydroxy-trans-2-decenoic acid, a unique unsaturated fatty acid of royal jelly, in stress-inducible depression-like mouse model," Evidence-Based Complementary and Alternative Medicine, vol. 2012, Article ID 139140, 6 pages, 2012.

[26] J. A. Rankin, "Biological mediators of acute inflammation," AACN Advanced Critical Care, vol. 15, no. 1, pp. 3-17, 2004.

[27] T. Thalhamer, M. A. McGrath, and M. M. Harnett, "MAPKs and their relevance to arthritis and inflammation," Rheumatology, vol. 47, no. 4, pp. 409-414, 2008.

[28] E. F. Wagner and Á. R. Nebreda, "Signal integration by JNK and p38 MAPK pathways in cancer development," Nature Reviews Cancer, vol. 9, no. 8, pp. 537-549, 2009.

[29] M. S. Hayden and S. Ghosh, "Signaling to NF- $\kappa$ B," Genes \& Development, vol. 18, no. 18, pp. 2195-2224, 2004.

[30] T. Sugiyama, K. Takahashi, A. Kuzumaki, S. Tokoro, P. Neri, and H. Mori, "Inhibitory mechanism of 10-hydroxy-trans-2decenoic acid (royal jelly acid) against lipopolysaccharide- and interferon- $\beta$-induced nitric oxide production," Inflammation, vol. 36, no. 2, pp. 372-378, 2013.

[31] K. Takahashi, T. Sugiyama, S. Tokoro, P. Neri, and H. Mori, "Inhibition of interferon- $\gamma$-induced nitric oxide production by 10-hydroxy-trans-2-decenoic acid through inhibition of interferon regulatory factor-8 induction," Cellular Immunology, vol. 273, no. 1, pp. 73-78, 2012.

[32] K. Takahashi, T. Sugiyama, S. Tokoro, P. Neri, and H. Mori, "Inhibitory effect of 10-hydroxydecanoic acid on lipopolysaccharide-induced nitric oxide production via translational downregulation of interferon regulatory factor1 in RAW264 murine macrophages," Biomedical Research (Japan), vol. 34, no. 4, pp. 205-214, 2013.

[33] K. Wang, J. Zhang, S. Ping et al., "Anti-inflammatory effects of ethanol extracts of Chinese propolis and buds from poplar (Populus $\times$ canadensis)," Journal of Ethnopharmacology, vol. 155, no. 1, pp. 300-311, 2014.

[34] K. J. Livak and T. D. Schmittgen, "Analysis of relative gene expression data using real-time quantitative PCR and the $2^{-\triangle \Delta \mathrm{CT}}$ method," Methods, vol. 25, no. 4, pp. 402-408, 2001.

[35] K. Wang, S. Ping, S. Huang et al., "Molecular mechanisms underlying the in vitro anti-inflammatory effects of a flavonoidrich ethanol extract from Chinese propolis (poplar type)," Evidence-Based Complementary and Alternative Medicine, vol. 2013, Article ID 127672, 11 pages, 2013.

[36] D. Granato, G. F. Branco, F. Nazzaro, A. G. Cruz, and J. A. F. Faria, "Functional foods and nondairy probiotic food development: trends, concepts, and products," Comprehensive Reviews in Food Science and Food Safety, vol. 9, no. 3, pp. 292302, 2010.

[37] K. Wang, L. Hu, X.-L. Jin et al., "Polyphenol-rich propolis extracts from China and Brazil exert anti-inflammatory effects by modulating ubiquitination of TRAF6 during the activation of NF- $\kappa$ B," Journal of Functional Foods, vol. 19, pp. 464-478, 2015.

[38] K. Wang, X. Jin, Y. Chen et al., "Polyphenol-rich propolis extracts strengthen intestinal barrier function by activating AMPK and ERK signaling," Nutrients, vol. 8, no. 5, p. 272, 2016.

[39] J. Majtán, E. Kováčová, K. Bíliková, and J. Šimúth, “The immunostimulatory effect of the recombinant apalbumin 1major honeybee royal jelly protein-on TNF $\alpha$ release," International Immunopharmacology, vol. 6, no. 2, pp. 269-278, 2006.

[40] J. Majtan, P. Kumar, T. Majtan, A. F. Walls, and J. Klaudiny, "Effect of honey and its major royal jelly protein 1 on cytokine 
and MMP-9 mRNA transcripts in human keratinocytes," Experimental Dermatology, vol. 19, no. 8, pp. e73-e79, 2010.

[41] X. Xu, P. Yin, C. Wan et al., "Punicalagin inhibits inflammation in LPS-induced RAW264.7 macrophages via the suppression of TLR4-mediated MAPKs and NF- $\kappa$ B activation," Inflammation, vol. 37, no. 3, pp. 956-965, 2014.

[42] K. Kohno, I. Okamoto, O. Sano et al., "Royal jelly inhibits the production of proinflammatory cytokines by activated macrophages," Bioscience, Biotechnology and Biochemistry, vol. 68, no. 1, pp. 138-145, 2004.

[43] A. Mantovani, P. Allavena, A. Sica, and F. Balkwill, "Cancerrelated inflammation," Nature, vol. 454, no. 7203, pp. 436-444, 2008.

[44] A. L. Groeger, C. Cipollina, M. P. Cole et al., "Cyclooxygenase2 generates anti-inflammatory mediators from omega-3 fatty acids," Nature Chemical Biology, vol. 6, no. 6, pp. 433-441, 2010.

[45] E. Scoditti, N. Calabriso, M. Massaro et al., "Mediterranean diet polyphenols reduce inflammatory angiogenesis through MMP9 and COX-2 inhibition in human vascular endothelial cells: a potentially protective mechanism in atherosclerotic vascular disease and cancer," Archives of Biochemistry and Biophysics, vol. 527, no. 2, pp. 81-89, 2012.

[46] S. Z. Sheikh, R. A. Hegazi, T. Kobayashi et al., "An antiinflammatory role for carbon monoxide and heme oxygenase1 in chronic Th2-mediated murine colitis," The Journal of Immunology, vol. 186, no. 9, pp. 5506-5513, 2011.

[47] D.-Q. Li, L. Luo, Z. Chen, H.-S. Kim, X. J. Song, and S. C. Pflugfelder, "JNK and ERK MAP kinases mediate induction of IL- $1 \beta$, TNF- $\alpha$ and IL- 8 following hyperosmolar stress in human limbal epithelial cells," Experimental Eye Research, vol. 82, no. 4, pp. 588-596, 2006.

[48] M. S. Hayden and S. Ghosh, "Shared Principles in NF- $\kappa$ B Signaling," Cell, vol. 132, no. 3, pp. 344-362, 2008. 


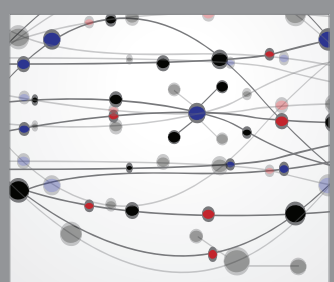

The Scientific World Journal
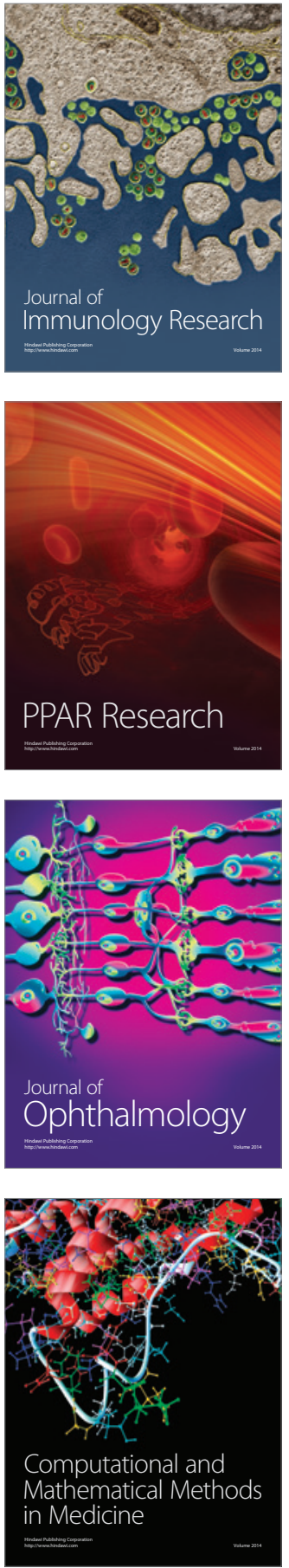

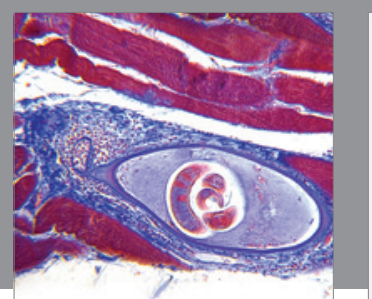

Gastroenterology Research and Practice

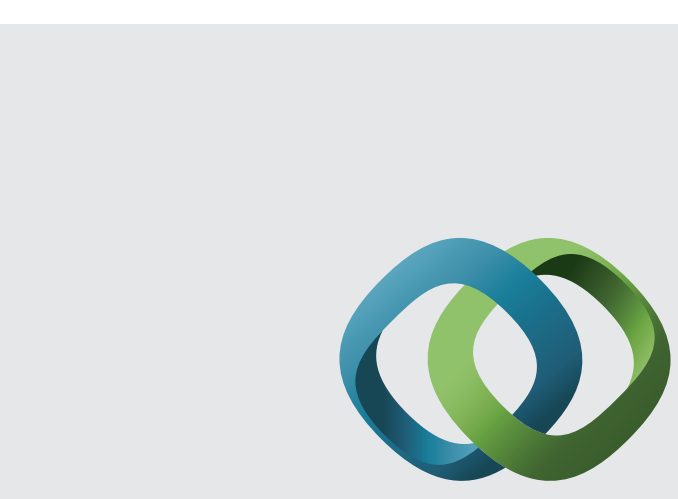

\section{Hindawi}

Submit your manuscripts at

http://www.hindawi.com
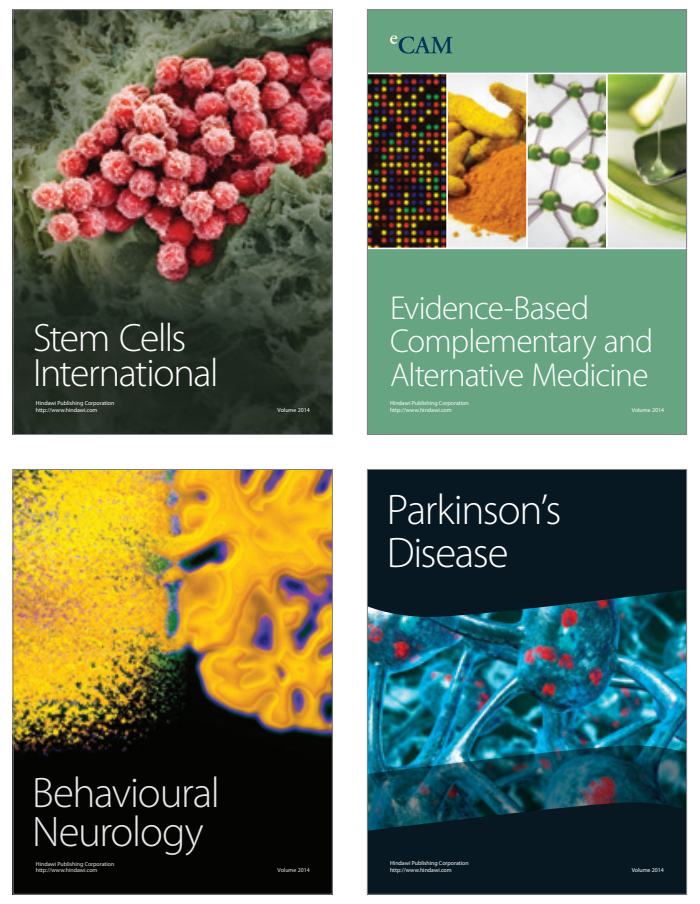
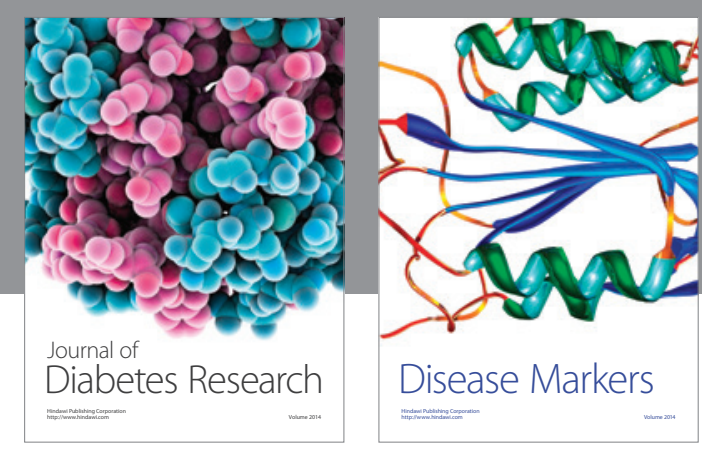

Disease Markers
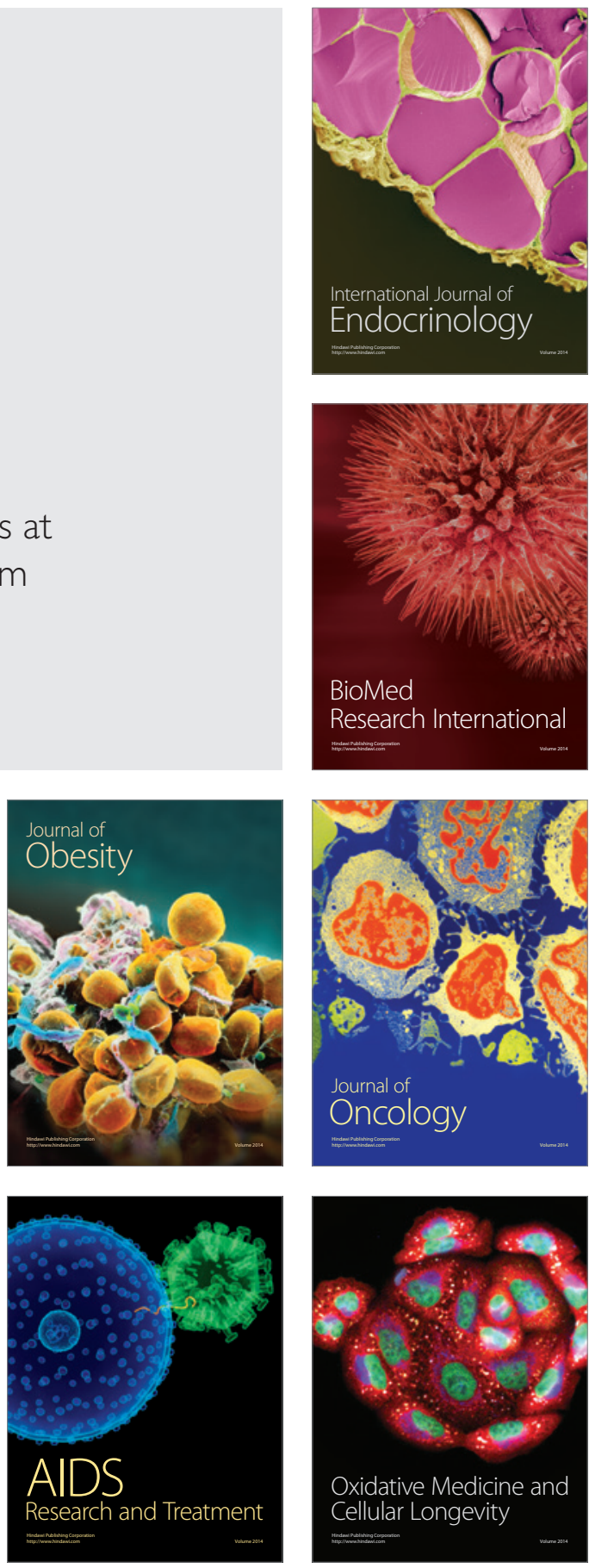